\title{
Interactive comment on "Communication strategies to address geo-hydrological risks: the POLARIS web initiative in Italy" by P. Salvati et al.
}

\section{P. Salvati et al.}

paola.salvati@irpi.cnr.it

Received and published: 27 April 2016

Please find enclosed the revised versione of the manuscript

Please also note the supplement to this comment:

http://www.nat-hazards-earth-syst-sci-discuss.net/nhess-2015-354/nhess-2015-354-

AC5-supplement.pdf

Interactive comment on Nat. Hazards Earth Syst. Sci. Discuss., doi:10.5194/nhess-2015-354, 2016.

Printer-friendly version

Discussion paper 